\title{
Illegal Construction Imposed by the Private Lands in Peripheral Urban Areas of M'sila, Algeria
}

\author{
Elhadj Benkhaled \\ Department of Urban Engineering \\ Institute of Urban Techniques Management \\ University of M'sila \\ M'sila, Algeria \\ elhadj.benkhaled@univ-msila.dz
}

\author{
Mohamed Mili \\ Department of Urban Engineering \\ Institute of Urban Techniques Management \\ University of M'sila \\ M'sila, Algeria \\ mohamed.mili@univ-msila.dz
}

\author{
Fateh Oudina \\ Department of Urban Engineering \\ Institute of Urban Techniques Management \\ University of M'sila \\ M'sila, Algeria \\ fateh.oudina@univ-msila.dz
}

\begin{abstract}
Urban building lands are considered a scarce resource, which forces us to rationalize their use and assignment. They play an important role in shaping the urban space with all its components and determine its characteristics. The impact on urban space depends on the legal nature of the land, the density of buildings, and the quality of social cohesion. Like all Algerian cities, the city of M'sila has experienced, since the ' $90 \mathrm{~s}$, an increasing demand for building plots, especially in the outskirts which are mostly private properties. This situation directly contributed to the spread of illegal constructions and as a result, districts lack basic living conditions. This phenomenon appeared in the peripheral district called La Rocade. In this paper, we will attempt to identify the impact of the legal nature of land properties, particularly private ones, on the proliferation of illegal constructions in the outskirts of the city of $M$ 'sila. We will try to find solutions and alternatives to limit or stop its spread and propose urban interventions to restructure this district and integrate it into the existing urban space.
\end{abstract}

Keywords-outskirts; land ownership; private land; urban space; illegal construction

\section{INTRODUCTION}

Following the example of the majority of Algerian cities, the city of M'sila underwent, after the independence of Algeria in 1962, an important process of urbanization due to the natural increase of the population and the phenomenon of rural exodus [1]. This urbanization has been accompanied by an accelerated increase in the rate of land consumption to meet the strong demand for housing and public facilities [2]. The urbanization phenomenon was amplified at the beginning of the ' 90 s due to the poor political and security conditions that the country experienced during this period [3]. This has led to the emergence of new urban forms, particularly in the outskirts of the city [4]. As a result, two distinct forms of urbanization have been developed: The first concerns urbanization through the planning instruments established by the public authorities and the second illegal (illicit) constructions on private properties to the detriment of agricultural land [5]. Faced with the worrying situation of the propagation of illicit constructions, the public authorities were obliged to regularize these areas [6]. Operations were conducted by the promulgation of a set of legislative texts [7] setting the rules for bringing constructions into conformity and their completion, aiming to achieve a balance between the interest and needs of inhabitants in terms of housing and the public interest in urban planning according to the economic, social, environmental, cultural, and aesthetic dimensions [7]. However, the application of the law faces a set of challenges, particularly in the district called La Rocade, where most of the buildings are built illegally. Built on private lands, this district constitutes one of the most important components of the urban space of the city due to its location along the national road number 40 (RN 40), its area of over 68 hectares, its density of 70 dwellings per hectare, and its population of more than 45,000 inhabitants. Over the last 10 years, the public authorities have spent more than 5 billion Algerian dinars to improve the living conditions of the inhabitants of this district.

The proliferation of constructions without a building permit in the La Rocade district has prompted us to ask a series of fundamental questions: What is the influence of private land properties in determining the urbanization arrangements of M'sila? How to limit the spread of this type of illicit constructions? How to reorganize and improve the living conditions of the inhabitants of this district? Despite the difficulty of mastering the phenomenon of the proliferation of illegal constructions on land of a private legal nature, the aim of this research is to try to answer these questions. This could 
be done through an evaluation of the urban and architectural characteristics of the studied district, the proposal of solutions that could contribute to stopping the propagation of the phenomenon, the improvement of the living conditions of the inhabitants, and finally by seeking ways to involve the multiple urban actors, particularly the citizen.

\section{STUDY AREA}

M'sila is a city in the North-Central part of Algeria. The city has experienced two types of urban extension. The first concerns the various collective housing, residential subdivision, and public facility programs carried out by the public authorities on public land [8]. The second concerns, essentially, individual housing in the eastern outskirts of the city made on privately owned land [4]. This outskirt contains more than 4 districts, the most important of which is the La Rocade. This district was chosen as the study area because of its strategic location along the NR 40, its large surface area, its high residential density, and the private legal nature of land ownership. The district is surrounded by private agricultural properties on the North, South, and East sides. The second reason is the significant number of observed illegal constructions (Figure 1).

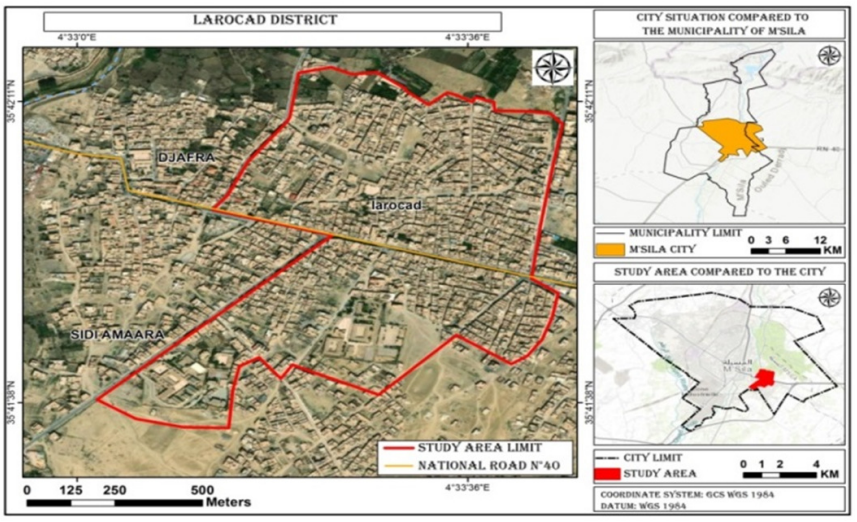

Fig. 1. Location of the study area (La Rocade district).

\section{Methodology}

The urban dynamic in the eastern outskirts of the city of M'sila was noticed during the '90s by the emergence of illegal dwellings on private lands. This situation has become worrying for the local public authorities. In the present research, the methodological approach used associates the diachronic comparison between the directives of the graphic planning documents, in particular, the master plan of development and town planning (PDAU), the land use plan (POS), and cadastral plans [9] along with in situ observation. This analysis was supplemented by an administrative survey through a series of semi-structured interviews with urban stakeholders. Our analysis is based on 3 elements, namely the legal nature of lands, the construction type, and the land market. To carry out our plans, we relied on architectural survey, taking photos, AutoCad software, and the Geographic Information System (GIS).

\section{RESULTS AND DISCUSSION}

\section{A. Evolution of the Nature of Land Ownership and its Effect on Urban Extension}

The legal nature of land properties may change according to the different stages of the historical development of the city in relation to the nature of the political system, especially in administrative and legislative aspects, management strategies, and town planning instruments [10]. We found it useful to do a spatial reading through in which we highlight the stages of the urban development of M'sila through the nature of land proprieties, the emergence of different urban forms, and the direction of extension relative to each period of development.

At the beginning of the creation of M'sila, which dates back to $1015 \mathrm{AD}$, the land properties belonged to individuals or to the various tribes of the nearby agro-pastoral villages. During the French colonization, the administration proceeded to a restructuring of all the properties in order to be reassign and allocate them to European owners according to the plan of the senatus consulte of the city established in 1905 [12]. This plan played an important role in determining the directions of the urban extension of the city. The general shape of the urban tissue has been configured in an oval shape due to its location within large areas of private agricultural land and crossed by a natural element which is the El-Ksob River [8]. As for the lands intended for construction, they were very limited, which produced a contrast between the components of the urban tissue, where there were dwellings attached to each other. This succession of adjacent dwellings is due to the increasing evolution of members of the same family [11]. The French authorities carried out cadastral operations covering a total area estimated at 13,950 hectares where they counted more than $53 \%$ of land of private and tribal property, located mostly in the eastern part of the El-Ksob River. The area of public property was estimated at around $47 \%$, of which $19 \%$ was owned by the state and $28 \%$ by the commune (communal property). The majority of these public properties are located in the western part of the city [12].

This radical change of property nature of all the lands of the city of M'sila, in particular in its western part had a direct and significant impact on the determination of the direction of urban growth towards the northwest side of the city. It allowed the emergence of new urban and architectural forms and typologies. The colonial city is structured by perpendicular streets and individual dwellings lined up in city blocks that are almost identical in terms of shape, area, and size. These constructions are aligned symmetrically along the main and secondary ways. Due to the oppressive colonial policy towards the natives of the villages and surrounding areas, and the modern facilities and services of the European district [11], most of their inhabitants sought to find stability near the existing urban core. The year 1958 marks the beginning of the appearance of the La Rocade district along the NR 40 which crosses the town of M'sila. This district appeared as an alternative urban area to the European district given the scarcity of building land in the western part of the city. In contrast, in the eastern part of the city, private land was easy to divide and sell under customary contracts. 
After the independence of Algeria, the French left the city leaving behind vacant properties and many developed and constructible spaces in the northwest part of the city. At the same time, a significant rural exodus has taken place in the absence of regulatory and legislative texts to guide the city's growth. Public land ownership played a preponderant role in determining the orientation of the urban extension towards this direction, because it did not present an administrative or legal constraint, in addition to its subsequent allocation as a constructible area defined by the town planning instruments. At the beginning of the '90s, the urban space of M'sila experienced a new mode of operation and management through mechanisms and means adapted to the aspirations and requirements of this period. The law number $90 / 29$, related to the development and town planning, was promulgated to organize and manage urban areas through two fundamental tools: PDAU and POS [13]. The guidelines for town planning and the directions of urban extensions of M'sila were defined by the PDAU plan. The whole urban area was divided into eleven (11) sectors. These sectors are areas that are already built up, building lands, or designated for future urbanization Most of the sectors are oriented towards the western part of the city due to the existence and availability of public land properties[14] (see Figure 2-3).

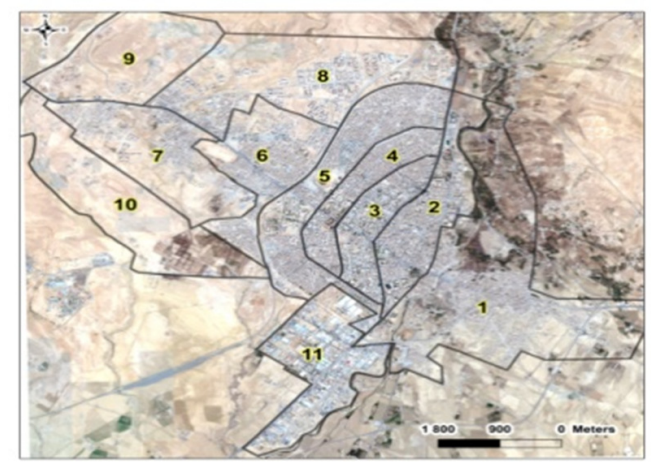

Fig. 2. Division of the urban area of M'sila.

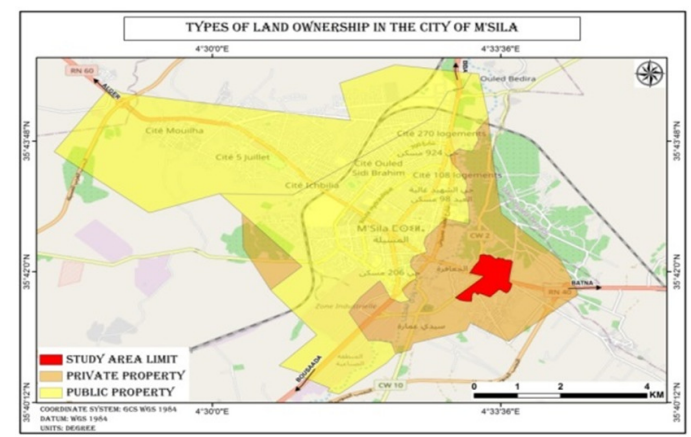

Fig. 3. Tupes of land ownership in M'sila.

According to the stages analysis of the urban development of the city of M'sila, we note that the nature of the land ownership was often at the origin of the determination of the general configuration of the city. This happened either directly in the production of the forms of buildings and districts, as we noted in the first core, or indirectly, after the conversion of the nature of land ownership, as was the case of the buildings of the colonial era. On the other hand, the nature of land ownership played a major role in determining the direction of the city's extension. Thus there has been a planned urban development towards the northwest side, where most of the land belongs to the State and does not present any administrative or legal problems, accompanied by the illegal urban development caused by the existence of private land properties in the eastern part. As for the extension to the southern part of the city, it was stopped by the creation of the industrial area (Figures 3-4).

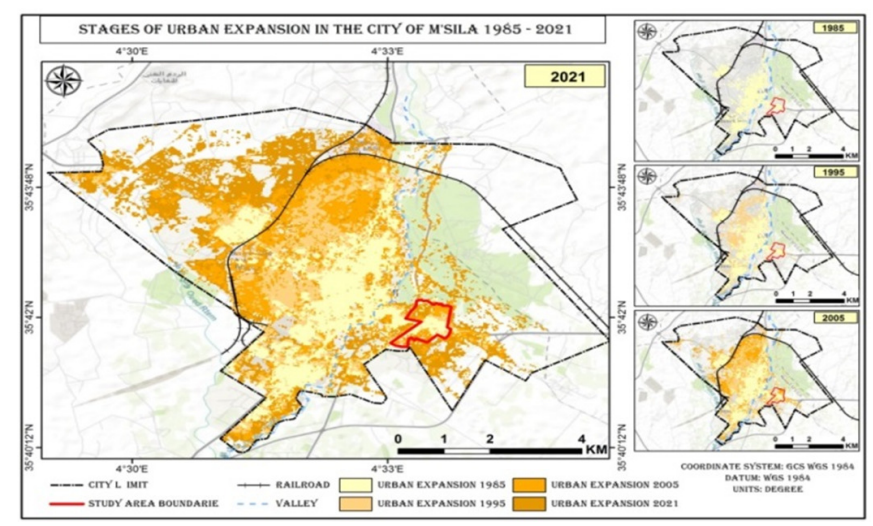

Fig. 4. Stages of urban expansion in the city of M'sila, 1985-2021.

\section{B. Illegal Construction: A Response to the Constraints of High Land} Prices and the Scarcity of Building Land

The free market economy policy adopted by the Algerian government after the promulgation of Law number 25/90 is seen as an explicit declaration of the new land policy. All restrictions on the willingness of individuals to buy or sell land have been lifted. Thus, the land market through supply and demand has become the only parameter determining the prices of real estate on the basis of the agreements concluded between the contracting parties $[15,16]$. This change in land policy has had major repercussions on the urban space of M'sila due to the large, rapid, and continuous increases in the land, particularly building land, prices. Land transactions have become compliant with the current regulations and are carried out on the basis of notarial deeds in accordance with the approved urban plans. For example, we cite the subdivision of 924 plots located about $4 \mathrm{~km}$ from the city center, where the price per square meter of building land exceeded 100,000 Algerian dinars in 2020 (or nearly 800 Euros). As for the city center (Ouaoua Madani district), the price per square meter has crossed 200,000 Algerian dinars (or nearly 1600 Euros) per square meter. Considering the excessive prices of building land on the one hand, and the persistent high demand for building plots due to the housing crisis on the other, it was mandatory for low-income citizens to seek the cheapest possible alternative to acquire a home. La Rocade district, located in the east of the city, offered them this basic need. The price of square meter is low $(15,000 \mathrm{DA}$ or nearly 75 Euros per square metre) and affordable, transactions were made by customary contracts in most cases and the land is sold without servicing or landscaping. 
TABLE I. AVERAGE PRICE OF URBAN LAND, 1940-1985 COMMAND ECONOMY PERIOD

\begin{tabular}{|c|c|c|c|c|c|}
\hline \multicolumn{5}{|c|}{ Command economy period } & Designation \\
\hline 1985 & 1980 & 1975 & 1960 & 1940 & Year \\
\hline 165 & 150 & 100 & 80 & 20 & Urban extension (ha) \\
\hline 52.3 & 40.2 & 29.5 & 19.2 & 5 & $\begin{array}{c}\text { Population } \\
\text { (thousands) }\end{array}$ \\
\hline 317 & 268 & 295 & 240 & 250 & $\begin{array}{c}\text { Habitat density } \\
\text { (h/ha) }\end{array}$ \\
\hline 300 & 100 & 20 & $/ /$ & $/ /$ & Cost of $\mathrm{m}^{2}$ \\
\hline
\end{tabular}

TABLE II. AVERAGE PRICE OF URBAN LAND, 1990-2018 FREE MARKET ECONOMY PERIOD

\begin{tabular}{|c|c|c|c|c|c|c|}
\hline \multicolumn{6}{|c|}{ Free market economy period } & \multirow{2}{*}{$\begin{array}{c}\text { Designation } \\
\text { Year }\end{array}$} \\
\hline 2018 & 2008 & 2005 & 2000 & 1995 & 1990 & \\
\hline 900 & 400 & 350 & 250 & 200 & 180 & $\begin{array}{l}\text { Urban extension } \\
\text { (ha) }\end{array}$ \\
\hline 650 & 135 & 121 & 109 & 99.5 & 60.3 & $\begin{array}{l}\text { Population } \\
\text { (thousands) }\end{array}$ \\
\hline 850 & 337 & 347 & 365 & 467 & 335 & $\begin{array}{c}\text { Habitat density } \\
(\mathrm{h} / \mathrm{ha})\end{array}$ \\
\hline 100000 & 30000 & 20000 & 5000 & 3000 & 1000 & Cost of $\mathrm{m}^{?}$ \\
\hline
\end{tabular}

\section{Descriptive Analysis of the Components of the Urban Tissue of the Study Case}

The La Rocade district occupies an area of 68 hectares with an irregular geometric shape. The characteristics of this spatial configuration are determined by the nature of the land properties which are considered as private agricultural land. The NR 40 is the main road axis which crosses the district. The structure of all the streets of the urban tissue is organized perpendicular to this main axis. The majority of these streets are characterized by small, variable, non-uniform width and a tortuous alignment. As for the built plots, they are irregular in shape crossed by narrow dead-end streets [17]. The land areas range from $600 \mathrm{~m}^{2}$ to $8000 \mathrm{~m}^{2}$. Sometimes we find free spaces between the plots in the form of very small cavities not exceeding $200 \mathrm{~m}^{2}$. These free spaces are used for social exchanges, especially for women, between neighbors and for playgrounds. The owners of private lands seek to maximize the profitability of the sale of plots reserved for construction (see Figure 5).

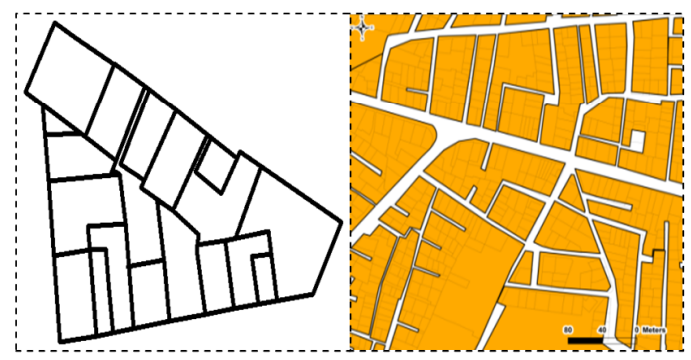

Fig. 5. The general form of the division of the islands.

The dwellings lined up and juxtaposed along the winding streets are of irregular and variable shape and have surface area ranging from $100 \mathrm{~m}^{2}$ to $400 \mathrm{~m}^{2}$. The buildings have heights that vary from $6 \mathrm{~m}$ (ground floor plus one floor) to $9 \mathrm{~m}$ (ground floor plus two floors). The terracotta brick is the most used material given its availability and its affordable price (Figure 6).

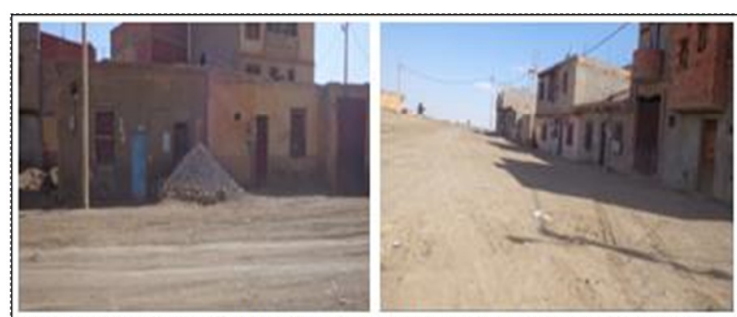

Fig. 6. Building materials and heights.

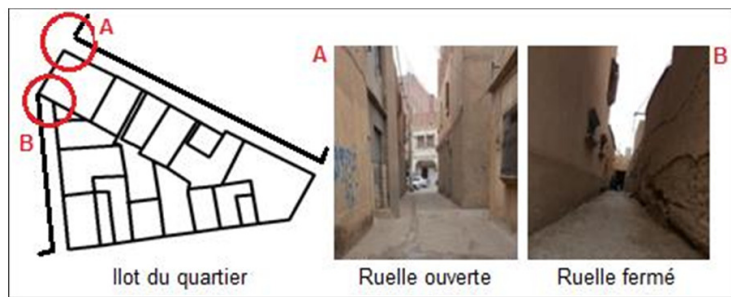

Fig. 7. The road network

The road network is a mix between the grid system and the tree system. Some alleys are primary with a width up to $12 \mathrm{~m}$ and others are dead ends with a width not exceeding $2.5 \mathrm{~m}$. The various commercial activities are carried out mainly along the principal axis of the NR 40 (Figure 7).

\section{CONCLUSION}

Through the study of the district and the analysis of its land use plan, we can conclude that private properties, which are estimated to be more than $95 \%$ of the total land area, have played an important role in determining the shape of the urban tissue. A tissue characterized by irregular and varied plots in terms of shapes, geometries, and areas. This inconsistency and disorganization are the result of the system of division adopted by the owners of land which was initially agricultural and was later transformed into building land. Their principle was to sell most of the land and to leave only small alleys to ensure accessibility. This act of division of building land produced constructions lined up along the national road with significant commercial activity, while extensions were made behind this main axis. These extensions were characterized by the appearance of adjacent illegal constructions. The buildings form continuous blocks separated only by windings, dead ends, and narrow alleys, and an urban tissue that does not meet the modern daily needs. The logic of profitability and easy gain adopted by the private land owners also had a negative impact on the spaces reserved for public facilities.

From the above, it becomes clear that private land properties sold to poor housing seekers had a considerable effect on the emergence of particular architectural and urban forms. Consequently, a number of solutions must be proposed to possibly help limit the spread of illegal constructions in the outskirts of the city of M'sila. Among the solutions we can mention:

- The awareness aspect: An awareness campaign through the media while involving the various social institutions (associations, mosques, schools, etc.). During this campaign, we must educate citizens to proceed with the 
regularization of their illegal construction according to the current regulations.

- The management aspect: It is a question of speeding up the diagnostic studies and the census of all illegal constructions. Then, the implementation of land use plans with continued control of urban space development follows. It is also necessary to work on the stability between housing supply and demand.

- The legal aspect: It is necessary to know the nature of the properties of the urban area by carrying out a global cadastral survey. It is also necessary to reform the legislative texts in order to adapt them to the current reality of the city. It is necessary to opt for the reduction of the documents requested in the constitution of building permit files and construction conformity certificates.

- The economic aspect: The development of an efficient and well-controlled system for subsidies intended for lowincome families. Grants can be financial loans, without interest, repayable one the long term.

\section{REFERENCES}

[1] K. Bachar, "La (re)production urbaine en Algérie à travers le logement social collectif. La pérennisation d'un modèle devenu la norme," Les Annales de la recherche urbaine, vol. 113, no. 1, pp. 54-65, 2018, https://doi.org/10.3406/aru.2018.3272.

[2] F. T. Benaissa and B. Khalfallah, "Industrial Activity Land Suitability Assessment Using Delphi and AHP to Control Land Consumption": The Case Study of Bordj Bouarreridj, Algeria," Engineering, Technology \& Applied Science Research, vol. 11, no. 5, pp. 7738-7744, Oct. 2021, https://doi.org/10.48084/etasr.4362.

[3] B. Drobenko, Droit de l'urbanisme. Paris, France: Berti Editions, 2007.

[4] H. Boutabba, M. Mili, and A. Farhi, "The Huḍni society in Algeria: Colonization and transformation of forms of domestic habitat (late 19th mid 20th century)," Espaces et societes, vol. 179, no. 4, pp. 161-184, 2019.

[5] M. Mili, H. Boutabba, and S.-D. Boutabba, "La nature urbaine: dégradation quantitative et qualitative des espaces verts urbains, cas de la ville steppique de M'Sila, Algérie," Revista Brasileira de Gestão Urbana, vol. 11, Aug. 2019, https://doi.org/10.1590/2175-3369.011. e20180138.

[6] H. Benkhaled, "Paysage urbain de la ville entre dialectique de la législation et la réalité d'application de la loi 08/15. Cas du lotissement 1093 Lots à M'sila," Courrier du Savoir Scientifique et Technique de l'Université Mohamed Khider de Biskra, 2018.

[7] Loi $n^{\circ}$ 8-15: Fixant les règles de mise en conformité des constructions et de leur achèvement. Algeria, 2008.

[8] K. Loumi and A. Redjem, "Integration of GIS and Hierarchical MultiCriteria Analysis for Mapping Flood Vulnerability: The Case Study of M'sila, Algeria," Engineering, Technology \& Applied Science Research, vol. 11, no. 4, pp. 7381-7385, Aug. 2021, https://doi.org/10.48084/ etasr.4266.

[9] Décret exécutif $n^{\circ}$ 91-175 définissant les règles générales d'aménagement, d'urbanisme et de construction. Algeria, 1991.

[10] N. A. Benmatti, L'habitat du Tiers-Monde: cas de l'Algérie. Algeria: SNED, 1982.

[11] E. Noaime et al., "A Short Review of Influencing Factors of Islamic Architecture in Aleppo, Syria," Engineering, Technology \& Applied Science Research, vol. 10, no. 3, pp. 5689-5693, Jun. 2020, https://doi.org/10.48084/etasr.3447.

[12] Sénatus consult du douar de la ville de M'sila. M'sila, Algeria, 1905.

[13] Loi $n^{\circ} 04-05:$ Modifiant et complétant la loi $n^{\circ} 90-29$ du 01 Décembre 1990 relatif à l'aménagement et l'urbanisme. Algeria, 2004.
[14] "Rapport du Plan Directeur de l'Aménagement et de l'Urbanisme PDAU," Directorate of Town Planning, M'sila, Algeria, 2018.

[15] Loi n 90-25: Relatif à l'orientation foncière. Algeria, 1990.

[16] Loi $n^{\circ}$ 06-06: Portant loi de l'orientation de la ville. Algeria, 2006.

[17] S. Nahrath, F. Varone, and J.-D. Gerber, "Les espaces fonctionnels: nouveau référentiel de la gestion durable des ressources?," VertigO - la revue électronique en sciences de l'environnement, vol. 9, no. 1, May 2009, https://doi.org/10.4000/vertigo.8510. 